\title{
Which methods to choose to correct cell types in genome-scale blood-derived DNA methylation data?
}

\author{
Akhilesh Kaushal', Hongmei Zhang ${ }^{1 *}$, Wilfried JJ Karmaus ${ }^{1}$, Julie SL Wang ${ }^{2}$ \\ From 14th Annual UT-KBRIN Bioinformatics Summit 2015 \\ Buchanan, TN, USA. 20-22 March 2015
}

\section{Background}

High throughput methods such as microarray and DNA-methylation are used to measure the transcriptional variation due to exposures, treatments, phenotypes or clinical outcomes in whole blood, which could be confounded by the cellular heterogeneity $[1,2]$. Several algorithms have been developed to measure this cellular heterogeneity. However, it is unknown whether these approaches are consistent, and if not, which method(s) perform better.

\section{Materials and methods}

The data implemented in this study were from a Taiwan Maternal and Infant Cohort Study [3,4]. We compared five cell-type correction methods, including four methods recently proposed: the method implemented in the minfi $\mathrm{R}$ package [5], the method by Houseman et al. [6], FaST-LMM-EWASher [7], RefFreeEWAS [8]) and one method using surrogate variables [9] (SVAs). The association of DNA methylation at each CpG site across the whole genome with maternal arsenic exposure levels was assessed adjusting for the estimated cell-types. To further demonstrate and evaluate the methods that do not require reference cell types, we first simulated DNA methylation data at $150 \mathrm{CpG}$ sites across 600 samples based on an association of DNA methylation with a variable of interest (e.g., level of arsenic exposure) and a set of latent variables representing "cell types". We then simulated DNA methylation at additional CpG sites only showing association with the latent variables.

\footnotetext{
* Correspondence: hzhang6@memphis.edu

'Division of Epidemiology, Biostatistics, and Environmental Health, University of Memphis, Memphis, TN 38152, USA.

Full list of author information is available at the end of the article
}

\section{Results}

Only 3 CpG sites showed significant associations with maternal arsenic exposure at a false discovery rate (FDR) level of 0.05, without adjusting for cell types. Adjustment by FaST-LMM-EWASher did not identify any CpG sites. For other methods, Figure 1 illustrates the overlap of identified CpG sites. Further simulation studies on methods free of reference data (i.e., FaST-LMM-EWASher, RefFreeEWAS, and SVA) revealed that RefFreeEWAS and SVA provided good and comparable sensitivities and specificities, and FaST-LMM-EWASher gave the lowest sensitivity but highest specificity (Table 1).

\section{Conclusions}

The results from real data indicated RefFreeEWAS and SVA were able to identify a large number of $\mathrm{CpG}$ sites, and results from SVA showed the highest agreement with all other approaches. Simulation studies further

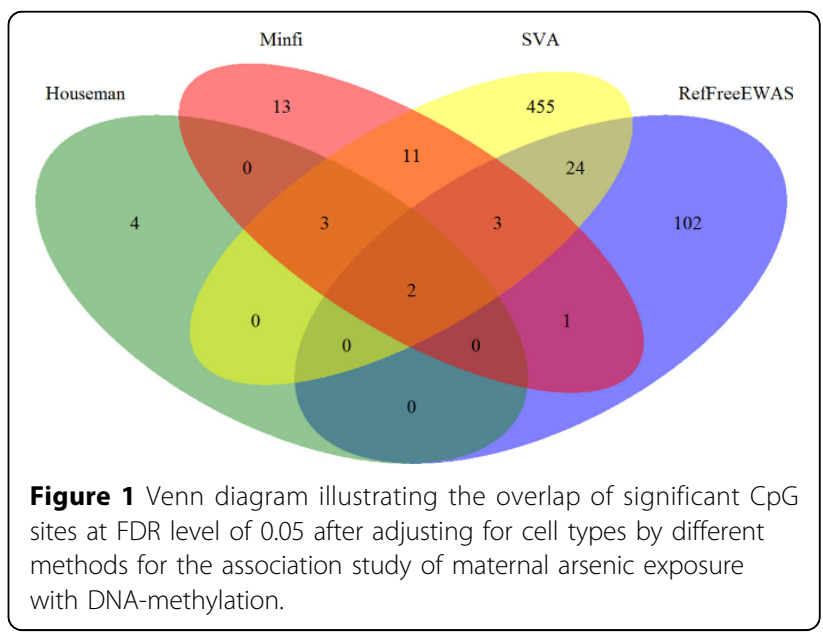


Table 1 Sensitivity and specificity with respect to truly identified variables using 100 simulated data; $\mathrm{Cl}$ : confidence interval

\begin{tabular}{lcc}
\hline & $\begin{array}{c}\text { Sensitivity: Median } \\
\mathbf{( 9 5 \%} \mathbf{C l})\end{array}$ & $\begin{array}{c}\text { Specificity: Median } \\
\mathbf{( 9 5 \% ~ C l )}\end{array}$ \\
\hline FaST-LMM-EWASher & $0.00(0.00,0.52)$ & $1.00(0.99,1.00)$ \\
RefFreeEWAS & $0.98(0.00,1.00)$ & $0.94(0.93,1.00)$ \\
SVA & $1.00(0.98,1.00)$ & $0.94(0.93,0.94)$ \\
\hline
\end{tabular}

confirmed that RefFreeEWAS and SVA are comparable and perform better than FaST-LMM-EWASher. Overall, the findings support a recommendation of using SVA to adjust for cell types due to its highest agreement with other methods and appealing findings from simulation studies.

\section{Authors' details}

'Division of Epidemiology, Biostatistics, and Environmental Health, University of Memphis, Memphis, TN 38152, USA.. ${ }^{2}$ Division of Environmental Health \& Occupational Medicine, National Health Research Institutes, Miaoli, 360 Taiwan.

Published: 23 October 2015

\section{References}

1. Adalsteinsson BT, Gudnason $H$, Aspelund T, Harris TB, Launer $L$, Eiriksdottir G, Smith AV, Gudnason V: Heterogeneity in white blood cells has potential to confound DNA methylation measurements. PloS one 2012, 7(10):e46705

2. Talens RP, Boomsma DI, Tobi EW, Kremer D, Jukema JW, Willemsen G, Putter H, Slagboom PE, Heijmans BT: Variation, patterns, and temporal stability of DNA methylation: considerations for epigenetic epidemiology. FASEB journal : official publication of the Federation of American Societies for Experimental Biology 2010, 24(9):3135-3144.

3. Lin L-C, Wang S-L, Chang Y-C, Huang P-C, Cheng J-T, Su P-H, Liao P-C: Associations between maternal phthalate exposure and cord sex hormones in human infants. Chemosphere 2011, 83(8):1192-1199.

4. Wang S-L, Su P-H, Jong S-B, Guo YL, Chou W-L, Päpke O: In utero exposure to dioxins and polychlorinated biphenyls and its relations to thyroid function and growth hormone in newborns. Environmental health perspectives 2005, 1645-1650.

5. Jaffe $A E$, Irizarry RA: Accounting for cellular heterogeneity is critical in epigenome-wide association studies. Genome biology 2014, 15(2):R31.

6. Houseman EA, Accomando WP, Koestler DC, Christensen BC, Marsit CJ, Nelson $\mathrm{HH}$, Wiencke JK, Kelsey KT: DNA methylation arrays as surrogate measures of cell mixture distribution. BMC bioinformatics 2012, 13:86.

7. Zou J, Lippert C, Heckerman D, Aryee M, Listgarten J: Epigenome-wide association studies without the need for cell-type composition. Nature methods 2014, 11(3):309-311.

8. Houseman EA, Molitor J, Marsit CJ: Reference-free cell mixture adjustments in analysis of DNA methylation data. Bioinformatics 2014, 30(10):1431-1439.

9. Leek JT, Storey JD: Capturing heterogeneity in gene expression studies by surrogate variable analysis. PLoS genetics 2007, 3(9):e161.

doi:10.1186/1471-2105-16-S15-P7

Cite this article as: Kaushal et al: Which methods to choose to correct cell types in genome-scale blood-derived DNA methylation data? BMC Bioinformatics 2015 16(Suppl 15):P7.

\section{Submit your next manuscript to BioMed Central} and take full advantage of:

- Convenient online submission

- Thorough peer review

- No space constraints or color figure charges

- Immediate publication on acceptance

- Inclusion in PubMed, CAS, Scopus and Google Scholar

- Research which is freely available for redistribution

Submit your manuscript at www.biomedcentral.com/submit 